Hydrol. Earth Syst. Sci. Discuss., 7, 1569-1587, 2010 www.hydrol-earth-syst-sci-discuss.net/7/1569/2010/

(C) Author(s) 2010. This work is distributed under the Creative Commons Attribution 3.0 License.
Hydrology and Earth System Sciences Discussions

This discussion paper is/has been under review for the journal Hydrology and Earth System Sciences (HESS). Please refer to the corresponding final paper in HESS if available.

\title{
Runoff response time of a loosely defined supraglacial microbasin
}

\section{Scott Munro}

Deptartment of Geography, University of Toronto Mississauga, Mississauga, ON L5L 1C6, Canada

Received: 15 January 2010 - Accepted: 24 January 2010 - Published: 25 February 2010 Correspondence to: D. Scott Munro (scott.munro@utoronto.ca)

Published by Copernicus Publications on behalf of the European Geosciences Union.

\section{HESSD}

$7,1569-1587,2010$

Runoff response time of a loosely defined supraglacial microbasin

D. Scott Munro

\section{Title Page}

Abstract

Conclusions

Tables

14

4

Back
Introduction

References

Figures

$\rightarrow$

Close
Full Screen / Esc

Printer-friendly Version

Interactive Discussion 


\section{Abstract}

A micrometeorological experiment was conducted in the summer of 2008 , at Peyto Glacier, during four meltwater production periods of $1,3,4$ and 5 days duration, the last two days marked by late summer snow cover. The data include a breakdown of 5 net radiation into its short- and long-wave components, as well as wind speed, temperature and humidity profile data for use in bulk transfer estimates of sensible heat and moisture transfer. In addition, a hydrological experiment was conducted, the data comprising sonic sounder measurements of ablation and stage level records of discharge from a supraglacial microbasin. As expected, the ratio of daily average runoff flow (low estimates is less than one on most days because of weathering crust development. Also, the conversion of stage level data into discharge from a supraglacial catchment presents challenges, notably defining the area of a loosely defined basin and specifying stage level on a downward moving surface. Nevertheless, it is clear that peak discharge lags peak meltwater energy input by periods of four to six hours. A suitably lagged flow estimate can be achieved by passing the flow through a simple storage reservoir, using delay times of $14.5,15,7.5$ and $9 \mathrm{~h}$ for each respective measurement period. This suggests that a substantial part of the delay in runoff from a glacier basin is tied up in ice surface hydrological processes.

\section{Introduction}

20 The seasonal development of englacial and subglacial control of the glacier flow regime figures prominently in ideas about glacier basin runoff response time during the melt season (Flowers, 2008; Fountain and Walder, 1998). Field evidence from stream flow data measured below the glacier snout indicate a period of long delay early in the melt season, when the glacier is snow covered and the internal drainage system has yet to be shaped by meltwater influx, followed by a period of short delay following ice exposure and evolution of the englacial-subglacial drainage system. The quickening of

\section{HESSD}

7, 1569-1587, 2010

Runoff response time of a loosely defined supraglacial microbasin

D. Scott Munro

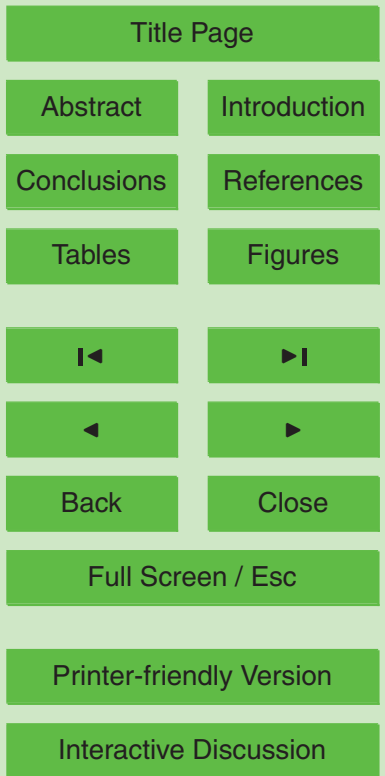


glacier runoff response due to ice exposure as opposed to internal drainage development is difficult to determine from basin runoff data though Hannah and Gurnell (2001), working with runoff data from a cirque glacier basin, identified much longer runoff delay from snow cover than from ice cover, such that they could be modelled respectively as 5 slow and fast runoff reservoirs.

The findings of 3 to $13 \mathrm{~h}$ fast reservoir storage coefficients (Gurnell, 1993; Hannah and Gurnell, 2001; Oerter et al., 1981) suggest that much of the delay is tied up in the internal drainage system of the glacier. This is supported by such data as are available from supraglacial runoff studies based on precisely defined microbasin areas on the glacier surface. They suggest much shorter delays in runoff response to surface melt water input, less than one hour (Derikx, 1971; Wendler and Ishikawa, 1973; Willis, Arnold and Brock, 2002), thus discounting the need to account for ice surface storage in runoff modelling.

The use of a precisely defined microbasin to study runoff response does consti15 tute a problem, however, in that neither the shape nor the flow behaviour of a natural supraglacial microbasin are necessarily well reflected in a precisely defined area, thus casting doubt upon the results. The purpose of this study is to revisit the question of supraglacial runoff response, based upon runoff response from a loosely defined microbasin area. Herein, the term "loosely defined" means that the area is defined by the apparent boundary of a supraglacial stream network without the use of flow barriers to isolate it from adjacent areas.

\section{Site and field methods}

\subsection{Microbasin definition and discharge measurements}

A microbasin was located on the tongue of the Peyto Glacier $\left(51^{\circ} 40^{\prime} \mathrm{N}, 116^{\circ} 33^{\prime} \mathrm{W}\right)$, at limits of the basin were obtained by instructing field assistants to follow a supraglacial

HESSD

$7,1569-1587,2010$

Runoff response time of a loosely defined supraglacial microbasin

D. Scott Munro

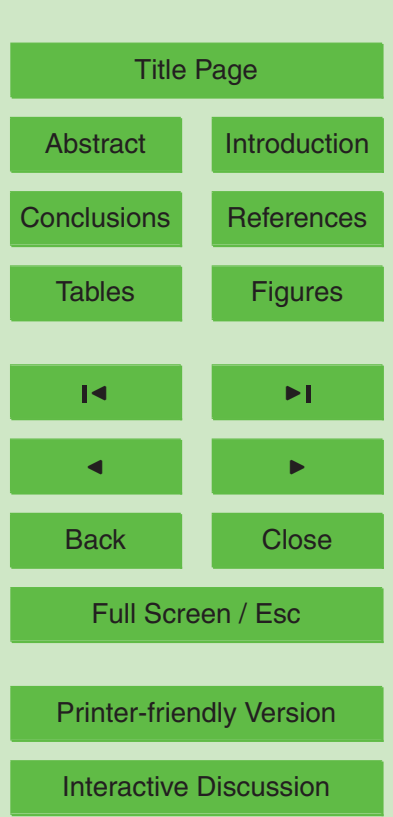


stream network upstream to its apparent limits, marking basin boundaries with readings from a hand-held global positioning system (GPS). In contrast to the rounded shape of a precisely defined basin, the result obtained was a narrow, elongated basin that rose $\sim 100 \mathrm{~m}$ up glacier over a $600 \mathrm{~m}$ distance, covering an area of approximately $1200 \mathrm{~m}^{2}$

5 (Fig. 1). So defined, no effort was made to artificially delimit and control the area by way of using plastic sheeting or flow barriers.

Data were selectively obtained by focusing on fair weather periods, extending from midnight to midnight, within which high rates of day-time surface meltwater production were to be expected. Thus four measurement periods were obtained for the 2008 10 summer: 25 July, 5-7 August, 13-16 August and 23-27 August. The last period began with fair weather, but changed to cold weather and snowfall during the last two days of measurements.

Microbasin discharge was measured by installing a stage level recorder at the stream outlet (Fig. 1), such that a water level signal was provided by attaching a float to a potentiometer. A stage-discharge relationship was obtained by the velocity-area technique, using floats to estimate velocity. The stilling well for the potentiometer float was initially installed in a hole drilled $\sim 1 \mathrm{~m}$ into the stream bed, then subsequently redrilled as frequently as needed to compensate for ablation. Due to an on-going need to adjust the measurements for ablation, this was also measured at the site, using an acoustic sounder (Model SR50, Campbell Scientific, Canada) mounted on a cross bar between two poles drilled $\sim 3 \mathrm{~m}$ into the ice near the basin outlet (Fig. 1).

\subsection{Micrometeorological instrumentation and data acquisition}

Micrometeorological instruments were also installed near the basin outlet (Fig. 1) to provide data for energy budget estimates of surface meltwater production. They included two net radiometers (Model S-1, Swisteco, Switzerland), one of which was covered with polyethylene domes to admit the full radiation spectrum, the other with glass domes to allow only the short-wave part of the spectrum. A four-level wind speed, temperature and humidity system was also installed at 1,2, 4 and $6 \mathrm{~m}$ above the ice,

HESSD

$7,1569-1587,2010$

Runoff response time of a loosely defined supraglacial microbasin

D. Scott Munro

Title Page

Abstract Introduction

Conclusions

Tables

References

Figures

14

4

Back

Full Screen / Esc

Printer-friendly Version

Interactive Discussion 
that closest to the surface providing the data for calculations because it was likely to be least affected by potential boundary-layer flux divergence. Wind speeds were obtained from sensitive anemometers (Model 104, Thornthwaite, USA), temperatures and humidities from a ventilated wet-bulb psychrometer system (custom design, University of 5 Toronto Mississauga, Canada), using thermocouple thermometers.

Signals from all sensors were connected to a data logger (Model CR1000, Campbell Scientific, USA) and sampled at $5 \mathrm{~s}$ intervals. All signals were processed into five-minute averages, except those from the acoustic sounder which were retained as samples. Processed data were then down-loaded to a field computer during periodic 10 site visits. Due to signal noise in the ablation record it was first necessary to apply a Hamming filter (Hamming, 1989) to this record, using a five-point moving window, before proceeding with calculations. All calculation results were obtained by using the five-minute records as the data base and aggregated to half-hourly values, as is generally recommended for energy budget work whenever boundary-layer calculations are 15 involved.

\section{Theoretical approach}

\subsection{Surface energy exchange components}

Surface melt, $Q_{\mathrm{M}}$, depends upon radiative and turbulent energy exchange at the glacier surface:

$Q_{\mathrm{M}}=K_{*}-L_{*}+Q_{\mathrm{H}} \pm Q_{\mathrm{E}}$

in which $K_{*}$ is the net short-wave radiation, $L_{*}$ the net long-wave radiation, $Q_{H}$ the sensible heat transfer and $Q_{E}$ is the latent heat transfer due to water vapour exchange with the boundary-layer. The radiative transfers are readily obtained from the data: $K_{*}$ as a direct measurement, $L_{*}$ as a residual of the short-wave and all-wave measurements.
HESSD

$7,1569-1587,2010$

Runoff response time of a loosely defined supraglacial microbasin

D. Scott Munro

\section{Title Page}

Abstract Introduction

Conclusions

Tables References Figures

14

4

Back

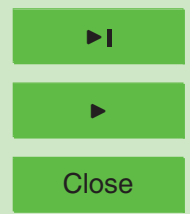

Full Screen / Esc

Printer-friendly Version

Interactive Discussion 
The sign convention reflects what is usually expected for air temperature above $0{ }^{\circ} \mathrm{C}$ : positive toward the surface.

The turbulent exchanges follow from the bulk transfer procedure, with correction for stability, and inclusion of aerodynamic and thermal roughness lengths, as described in 5 Munro $(1989,2004)$ and Andreas (2002). It is acknowledged that a simpler procedure is to optimize the bulk transfer coefficients to force closure between the right-handside of Eq. (1) and $Q_{\mathrm{M}}$ measurements (e.g., Oerlemanns, 2000), such as are available for this study from acoustic sounder data. While this can be an effective approach to take when estimating daily ablation over the course of a melt season, it may not be so effective when the goal is to aggregate half-hourly values from five-minute calculations.

More specifically, optimization is not chosen for this part of the analysis because of the:

1. preference to keep the energy exchange outcome of the analysis separate from any data that affect the outcome of the flow measurements, as do the acoustic sounder data

2. likelihood that such optimization may include the effects of weathering crust development (Müller and Keeler, 1969; Munro, 1990), which could be a factor in surface runoff response

3. need to use optimization to estimate runoff from the stilling well and acoustic sounder data, as well as to estimate storage delay times, and thus confine optimization to the hydrological aspect of the analysis.

\subsection{Estimation and measurement of supraglacial runoff}

The reason for using optimization to obtain runoff estimates is that it is unrealistic to obtain a consistent runoff estimation procedure for a loosely defined microbasin where, among other things, the location of the stilling well is melting downward at a rate that is not necessarily the same as measured by a nearby acoustic sounder. Other things

HESSD

$7,1569-1587,2010$

Runoff response time of a loosely defined supraglacial microbasin

D. Scott Munro

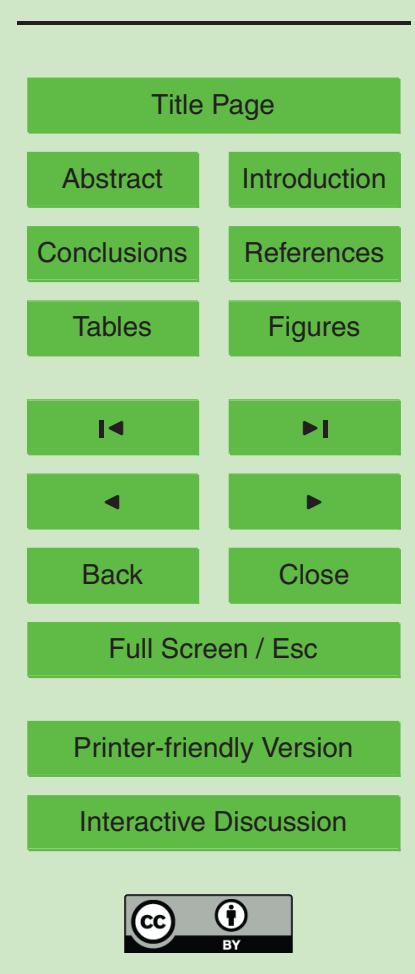


involve the fact that a GPS definition of basin area is not precise, nor is the area isolated from adjacent microbasins. As melt rates increase during the day, inflow to the study basin occurs from adjacent basins, as does outflow from the basin above the stilling well location. Thus one is faced with the problem of estimating runoff from a "leaky" 5 basin for which there is no manageable way to assess the magnitude and timing of the leaks.

The first step in optimization was to convert $Q_{M}$ to a water equivalent, taking the specific gravity of ice to be 0.89 , and multiplying by the microbasin area to obtain discharge estimates, $q^{\prime}$. The second was to obtain discharge measurements, $q$, from a standard head-discharge relationship (Linsley, Kohler and Paulhus, 1975):

$q=q_{0}\left(h / h_{0}\right)^{k}$

in which $h$ is stream height above a reference height, $h_{0}, q_{0}$ is set to one $\mathrm{Is}^{-1}$ and $k=2.53$ is established from the stage-discharge relationship obtained in the field. Optimization was then done to minimize the root-mean-square (RMS) difference between $15 q^{\prime}$ and $q$.

The optimization procedure consisted of first adjusting the measured ablation rate so that its application to stage data would not result in an upward or downward trend in the apparent base flow rate. Then $h$ was adjusted for step changes due to redrilling of the stilling well at the onset of measurements, and occasional resetting of the poten20 tiometer during measurement periods. Finally, $q_{0}$ was set to achieve the smallest RMS $q^{\prime}-q$

\section{Results and discussion}

\subsection{Energy exchange at the surface}

The fourth measurement period produced the longest series (Fig. 2), during which conditions changed from ice cover to snow cover over ice. The dominance of $K_{*}$ is

1575

\section{HESSD}

$7,1569-1587,2010$

Runoff response time of a loosely defined supraglacial microbasin

D. Scott Munro

\section{Title Page}

Abstract Introduction

Conclusions

Tables References Figures

14

4

Back

Close

Full Screen / Esc

Printer-friendly Version

Interactive Discussion 
evident throughout the series, as is the persistently negative $L_{*}$. The smaller $K_{*}$ values for the final two days of the series are the consequence of cloud cover and increased surface albedo due to snow. The strongest turbulent transfer is $Q_{\mathrm{H}}$, which is $\geq 0 \mathrm{~W} \mathrm{~m}^{-2}$ throughout the period, while $Q_{\mathrm{E}}$ is comparatively small and sometimes 5 negative in sign, especially during the final two days. A degree of caution is advised in regard to the turbulent transfer terms, particularly on the last two days of the sequence, because the assumed surface boundary condition for bulk transfer calculations is $0^{\circ} \mathrm{C}$, $6.11 \mathrm{hPa}$ throughout all measurement periods, thus discounting the possibility of a "below freezing" surface.

10 Daily averge results for all four periods in which midnight to midnight data were obtained are displayed in Table 1, where separation of the short-wave and long-wave radiation terms identifies $K_{*}$ to be the dominant contributor to $Q_{\mathrm{M}}$ on most days, followed by $Q_{H}$. The clearest sky conditions apply to the first three days listed, as evidenced by the result that these days have the greatest values of short-wave gain and long-wave 15 loss. The last three days listed are cloudiest, showing the smallest $K_{*}$ and $L_{*}$ averages and the effects of a late summer snow cover. Average wind speeds, $u$, on these days tend to be in the order of $4 \mathrm{~m} \mathrm{~s}^{-1}$, the highest on 15 August, lowest on 26 August. These days also mark, respectively, the highest and lowest averages of temperature, $T_{\mathrm{a}}$, vapour pressure, $e_{\mathrm{a}}$, and $Q_{\mathrm{M}}$.

20 The energy exchange results are as expected from previous work on this glacier at sites above and below that of the present location (Munro, 1990). Together, $K_{*}$ and $L_{*}$ would account for approximately $60 \%$ of the melt energy, the turbulent transfer terms for the remainder. $Q_{\mathrm{H}}$ and $Q_{\mathrm{E}}$, closely track their respective determinants, $T_{\mathrm{a}}$ and $e_{\mathrm{a}}$, negative $Q_{\mathrm{E}}$ values occurring when $e_{\mathrm{a}}$ is below $6.11 \mathrm{hPa}$. It is also noteworthy that $u$ inspection of the wind speed profile above $1 \mathrm{~m}$ showed the maximum wind speed to be typically at the $4 \mathrm{~m}$ measurement level, thus confirming the caution of using the lowest measurement level for bulk transfer calculations.

HESSD

$7,1569-1587,2010$

Runoff response time of a loosely defined supraglacial microbasin

D. Scott Munro

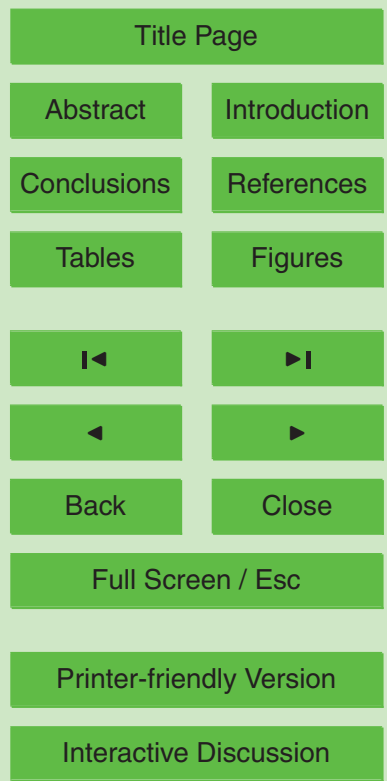




\subsection{Measured and estimated supraglacial runoff comparisons}

The flow rate series corresponding to Fig. 2 are shown in Fig. 3, where it appears that measured flow lags the flow estimates, particularly during the first and second days. Although this series does not provide especially good conditions for measured 5 and estimated flow comparisons, it does show the effect of late summer snow fall upon the supraglacial meltwater regime. Despite the effect of snow cover on "shutting down" glacier meltwater production, a small amount of surface runoff occurs during the snowfall days, as might be expected for water release from storage under snow cover, even to the extent that flow for the second snow day was less than that for the preceding day. Given the nature of the measurement procedure employed here, however, this result could well have been fortuitous.

Measurement and estimate comparisons are well exemplified in results from the third observation period (Fig. 4). Here, correction for surface level change was achieved by applying a 1.24 multiplier to the acoustic sounder data as opposed to 1.5 for the first two 15 periods and one for the fourth observation period. The RMS $\left(q^{\prime}-q\right)$ was minimized to $11.5 \mathrm{I} \mathrm{s}^{-1}$ by setting $h_{0}=8.4 \mathrm{~mm}$, the smallest of the three values used for this purpose (e.g., 36, 13 and $17 \mathrm{~mm}$ for periods 1,2 and 4, respectively). The RMS error is large relative to the flow rates plotted here, as it is for the other measurement periods (11.6, 12.1 and $7.3 \mathrm{I} \mathrm{s}^{-1}$, respectively), because there is no adjustment to the flow estimates 20 for response time.

It is evident that the lags in supraglacial runoff response are substantially longer than those reported from the precisely defined microbasins cited above. Peak flow measurements appear to occur as much as $6 \mathrm{~h}$ after the peak flow estimates (Fig. 4). Willis, Arnold and Brock (2002), reporting the results from a precisely defined microbasin in longer lag time of approximately $3 \mathrm{~h}$ being observed only when the surface was snow covered. The observation of lag times longer than $3 \mathrm{~h}$ for bare ice leaves one in search of a mechanism. One possibility is storage delay in the fabric of the weathering crust,

HESSD

7, 1569-1587, 2010

Runoff response time of a loosely defined supraglacial microbasin

D. Scott Munro

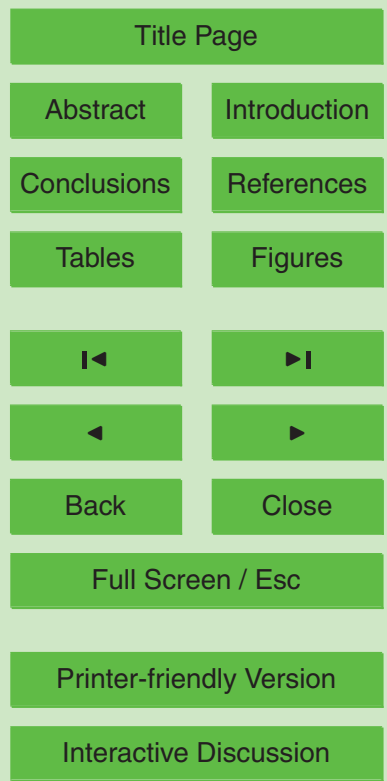


which has long been known to develop well on days of strong solar radiation (Müller and Keeler, 1969).

Pertinent to this, a look at the flow regime against the pattern of surface level measurements from the acoustic sounder reveals surface level variations that break down 5 into distinct day and night periods (Fig. 4). Peak estimated flows occur in mid-day, when weathering crust development due to $K_{*}$ would be most intensive, while peak measured flows occur near the transition from a day to a night period, when the weathering crust could be decaying as the turbulent transfer terms begin to dominate the surface energy regime. Thus it is possible to interpret late day peak flow as being due 10 to a combination of radiative-turbulent heat input and storage release from a decaying supraglacial reservoir. If so for a loosely-defined basin, however, why not also for a precisely defined basin where similar arguments about the effect of the weathering crust would apply?

\subsection{Supraglacial storage and runoff delay}

15 The question of storage was further explored by way of more optimization, using the reservoir approach decribed in Hannah and Gurnell (2001):

$q^{\prime \prime}=\frac{S}{K} ; S=S_{0}+\left(q^{\prime}-q^{\prime \prime}\right)_{0}$

in which adjusted flow, $q^{\prime \prime}$, from storage, $S$, depends upon delay time, $K$, and the subscript refers to the preceding step in the calculation sequence. Then minimization of the RMS $\left(q^{\prime \prime}-q\right)$ according to $K$ results in RMS values of $2.3,3.4,5.0$ and $3.1 / \mathrm{s}^{-1}$, respectively, for each measurement period, values that are less than half those that apply to the initial optimization. The corresponding $K$ values are $14.5,15,7.5$ and $9 \mathrm{~h}$, which are comparable to the range reported by Hannah and Gurnell for the fast response reservoir of an ice surface. The consequence is an adjusted flow with a pattern is smoother as expected from passing $q^{\prime}$ through a reservoir (Fig. 4).

\section{HESSD}

$7,1569-1587,2010$

Runoff response time of a loosely defined supraglacial microbasin

D. Scott Munro

\section{Title Page}

Abstract Introduction

Conclusions

Tables

References

Figures

14

4

Back

Full Screen / Esc

Printer-friendly Version

Interactive Discussion 
Bulk comparisons of $q, q^{\prime}$ and $q^{\prime \prime}$ were done by calculating $24 \mathrm{~h}$ flow averages for the 11 days during which supraglacial drainage was from bare ice cover (Table 2). An interesting aspect of the comparisons is that $q^{\prime}$ does not equate to $q$, but $q^{\prime \prime}$ does. The mean $q / q^{\prime}$ for the eleven days is $\sim 0.85$, while that of $q / q^{\prime \prime}$ is $\sim 1$, as one would expect 5 where sub-surface melting due to $K_{*}$ is involved. It is expected that a portion of the sub-surface melt would be retained in storage in the weathering crust each day, which is consistent with most of the $q / q^{\prime}$ ratios listed in the table being $<1$, while $q / q^{\prime \prime}$ ratios that vary around 1 are to be expected as the consequence of incorporating a storage mechanism. The results are also consistent with field comparisons between measured and estimated ablation (Müller and Keeler, 1969; Munro, 1990).

More insight on weathering crust development is gained by looking at $K_{*} / Q_{\mathrm{M}}$ (Table 2), where focus on the short-wave part of the net radiation isolates the radiation that penetrates the ice surface, thus acting as the principal agent of weathering crust development during daylight hours. By contrast the remaining terms, $L_{*}, Q_{\mathrm{H}}$ and $Q_{\mathrm{E}}$ act at the surface, with daylight $K_{*}$, as agents of weathering crust decay throughout the length of each day. Given the large $K_{*} / Q_{\mathrm{M}}$ ratios it would appear that the main agent of weathering crust development is much stronger than the agents of decay. Thus it seems that once weathering crust development occurs during a period of fair weather, the structure will persist throughout the period, only a little affected by night time decay.

\section{Concluding remarks}

The foregoing show that when weathering crust development is strong, as expected on high radiation days, there is substantial lag in supraglacial runoff response.

Although englacial and subglacial flow are key elements in the runoff delay from glacier basins, certainly on a day-to-day basis, supraglacial flow delay is also be imexpect from the work of Hannah and Gurnell (2001), but here it is clear that englacial and subglacial storage can have no effect upon the conclusions.

HESSD

7, 1569-1587, 2010

Runoff response time of a loosely defined supraglacial microbasin

D. Scott Munro

\section{Title Page}

Abstract Introduction

Conclusions

Tables

References

Figures

14

4

Back

Close

Full Screen / Esc

Printer-friendly Version

Interactive Discussion 
This still leaves unanswered the question posed above, as to why substantial delay should appear here, in a loosely defined basin, but not in precisely defined microbasins. It is possible that the answer lies in the shape of the basin, as pointed out in Linsley, Kohler and Paulhus (1975) where, on a much larger scale, elongated drainage basins 5 exhibit longer response times than rounded basins. What applies to the large scale of a river basin might apply to a microbasin like that of this study, thus entertaining the idea of topographical self-similarity (Kinkenberg and Goodchild, 1992). Thus it could be that the elemental hydrological response unit of the glacier ice surface is one for which the length far exceeds the width.

10 Acknowledgements. Research funding for this work was obtained through the Canada Foundation for Climate and Atmospheric Science in support of the Improved Processes Parameterization and Prediction in Cold Regions Research Network, Principal Investigator J. Pomeroy, University of Saskatchewan. Field infrastructure support was provided by way of the Canadian Glacier Variations Monitoring and Assessment Network, headed by M. N. Demuth, Natural Re15 sources Canada. Field assistants for the research were E. Hicks, University of Calgary, and

L. Comeau, University of Saskatchewan.

\section{References}

Andreas, E. L.: Parameterizing scaler transfer over snow and ice: a review, J. Hydrometeorol., 3, 417-432, 2002.

20 Derikx, L.: The heat balance and associated runoff from an experimental site on the glacier tongue, International Association of Scientific Hydrology Publication, 104, 59-69, 1971.

Flowers, G. E.: Subglacial modulation of the hydrograph from glacierized basins, Hydrol. Process., 22(19), 3903-3918, 2008.

Fountain, A. G. and Walder, J. S.: Water flow through temperate glaciers, Rev. Geophys., 36(3), 299-328, 1998.

Gurnell, A. M.: How many reservoirs? An analysis of flow recession from a glacier basin, J. Glaciol., 39, 409-414, 2001.

Hamming, R. W.: Digital Filters, New York, Dover, 284 pp., 1989.

HESSD

7, 1569-1587, 2010

Runoff response time of a loosely defined supraglacial microbasin

D. Scott Munro

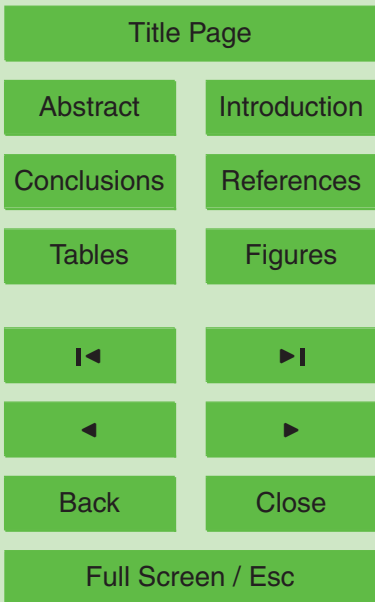

Printer-friendly Version

Interactive Discussion 
Hannah, D. M. and Gurnell, A. M.: A conceptual linear reservoir runoff model to investigate melt season changes in cirque glacier hydrology, J. Hydrol., 246, 123-141, 2001.

Klinkenberg, B. and Goodchild, M. F.: The fractal properties of topography: a comparison of methods, Earth Surf. Proc. Land., 17, 217-234, 1992.

5 Linsley, R. K., Kohler, M. A., and Paulhus, J. L. H.: Hydrology for Engineers, McGraw-Hill, New York, 482 pp., 1975.

Müller, F. and Keeler, C. M.: Errors in short-term ablation measurements on melting ice surfaces, J. Glaciol., 8, 91-105, 1969.

Munro, D. S.: Revisiting bulk heat transfer on the Peyto Glacier in light of the OG parameterization, J. Glaciol., 50, 590-600, 2004.

Munro, D. S.: Comparison of melt energy computations and ablatometer measurements on melting ice and snow, Arctic Alpine Res., 22, 153-162, 1990.

Munro, D. S.: Surface roughness and bulk heat transfer on a glacier: comparison with eddy correlation, J. Glaciol., 35, 343-348, 1989.

15 Oerlemans, J.: Analysis of a 3 year meteorological record from the ablation zone of the Morteratschgletscher, Switzerland, J. Glaciol., 46, 571-579, 2000.

Oerter, H., Baker, D., Moser, H., and Reinwarth, O.: Glacial-hydrological investigations at the Vernagtferner Glacier as a basis for a discharge model, Nord. Hydrol., 12, 335-348, 1981.

Wendler, G. and Ishikawa, N.: Experimental study of the amount of ice melt using three different methods: acontribution to the International Hydrological Decade, J. Glaciol., 12, 399-410, 1973.

Willis, I. C., Arnold, N. S., and Brock, B. W.: Effect of snowpack removal on energy balance, melt and runoff in a small supraglacial catchment, Hydrol. Process., 16, 1010-1018, 2002.

HESSD

7, 1569-1587, 2010

Runoff response time of a loosely defined supraglacial microbasin

D. Scott Munro

\section{Title Page}

Abstract Introduction

Conclusions

Tables

References

Figures

14

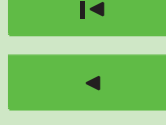

Back

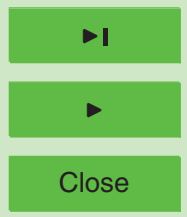

Full Screen / Esc

Printer-friendly Version

Interactive Discussion 


\section{HESSD}

7, 1569-1587, 2010

Table 1. Surface energy components and boundary-layer conditions averaged over $24 \mathrm{~h}$ periods.

\begin{tabular}{lrrrrrrrr}
\hline Day & $\begin{array}{r}Q_{\mathrm{M}} \\
\left(\mathrm{W} \mathrm{m}^{-2}\right)\end{array}$ & $\begin{array}{r}K_{*} \\
\left(\mathrm{~W} \mathrm{~m}^{-2}\right)\end{array}$ & $\begin{array}{r}L_{*} \\
\left(\mathrm{~W} \mathrm{~m}^{-2}\right)\end{array}$ & $\begin{array}{r}Q_{\mathrm{H}} \\
\left(\mathrm{W} \mathrm{m}^{-2}\right)\end{array}$ & $\begin{array}{r}Q_{\mathrm{E}} \\
\left(\mathrm{W} \mathrm{m}^{-2}\right)\end{array}$ & $\begin{array}{r}T_{\mathrm{a}} \\
\left({ }^{\circ} \mathrm{C}\right)\end{array}$ & $\begin{array}{r}e_{\mathrm{a}} \\
(\mathrm{hPa})\end{array}$ & $\begin{array}{r}u \\
\left(\mathrm{~m} \mathrm{~s}^{-1}\right)\end{array}$ \\
\hline 25 July & 246 & 239 & -67 & 73 & $\sim 0$ & 6.35 & 6.12 & 4.71 \\
5 August & 217 & 233 & -75 & 61 & -2 & 5.57 & 6.02 & 4.33 \\
6 August & 274 & 245 & -65 & 84 & 10 & 8.39 & 6.59 & 3.92 \\
7 August & 318 & 219 & -37 & 108 & 28 & 8.97 & 7.31 & 4.98 \\
13 August & 191 & 172 & -50 & 60 & 8 & 6.34 & 6.55 & 3.75 \\
14 August & 278 & 221 & -55 & 95 & 17 & 7.77 & 6.78 & 4.94 \\
15 August & 330 & 221 & -44 & 124 & 29 & 9.92 & 7.28 & 5.23 \\
16 August & 296 & 206 & -44 & 110 & 22 & 9.20 & 7.08 & 4.90 \\
23 August & 140 & 127 & -46 & 50 & 8 & 5.87 & 6.53 & 3.20 \\
24 August & 259 & 172 & -41 & 118 & 10 & 9.67 & 6.45 & 5.03 \\
25 August & 136 & 102 & -17 & 44 & 7 & 4.27 & 6.33 & 3.76 \\
26 August & 4 & 33 & -30 & 13 & -12 & 1.53 & 5.44 & 2.77 \\
27 August & 16 & 37 & -25 & 16 & -12 & 1.82 & 5.45 & 3.58 \\
\hline
\end{tabular}

Runoff response time of a loosely defined supraglacial microbasin

D. Scott Munro

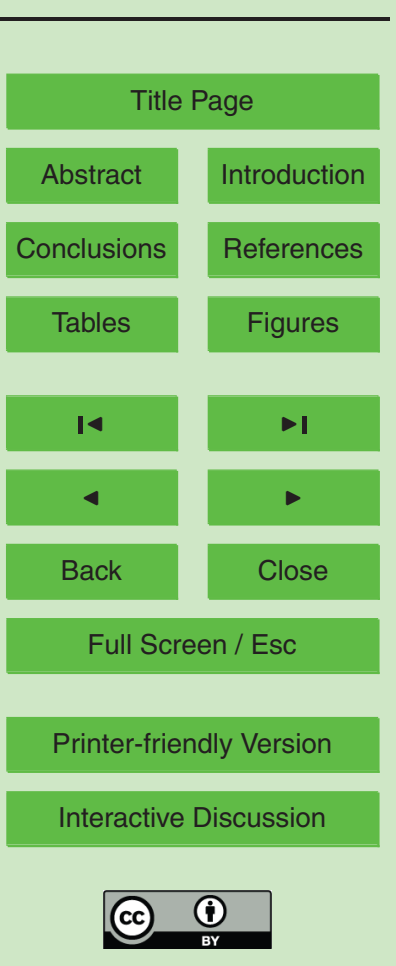




\section{HESSD}

7, 1569-1587, 2010

Runoff response time of a loosely defined supraglacial microbasin

Table 2. Daily microbasin flow comparisons and ratios for bare ice cover.

\begin{tabular}{lrrrrrr}
\hline Day & $K_{*} / Q_{\mathrm{M}}$ & $\begin{array}{r}q \\
\left(\mathrm{~s}^{-1}\right)\end{array}$ & $\begin{array}{r}q^{\prime} \\
\left(\mathrm{Is}^{-1}\right)\end{array}$ & $\begin{array}{r}q^{\prime \prime} \\
\left(\mathrm{Is}^{-1}\right)\end{array}$ & $q / q^{\prime}$ & $q / q^{\prime \prime}$ \\
\hline 25 July & 0.97 & 8.5 & 9.9 & 7.4 & 0.86 & 1.15 \\
5 August & 1.08 & 7.5 & 8.7 & 6.4 & 0.86 & 1.17 \\
6 August & 0.90 & 8.9 & 11.1 & 9.3 & 0.81 & 0.96 \\
7 August & 0.69 & 10.3 & 12.8 & 11.9 & 0.81 & 0.87 \\
13 August & 0.90 & 6.6 & 7.7 & 6.9 & 0.86 & 0.96 \\
14 August & 0.79 & 10.2 & 11.2 & 9.9 & 0.91 & 1.03 \\
15 August & 0.67 & 9.5 & 13.3 & 13.0 & 0.71 & 0.73 \\
16 August & 0.70 & 10.1 & 11.9 & 12.4 & 0.85 & 0.82 \\
23 August & 0.91 & 6.6 & 5.6 & 3.6 & 1.18 & 1.87 \\
24 August & 0.66 & 7.1 & 10.4 & 9.2 & 0.68 & 0.77 \\
25 August & 0.75 & 5.1 & 5.5 & 7.3 & 0.93 & 0.69 \\
\hline
\end{tabular}

D. Scott Munro

\section{Title Page}

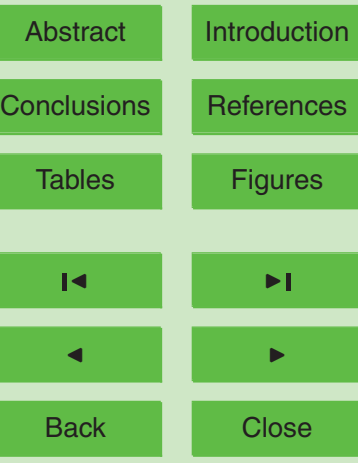

Full Screen / Esc

Printer-friendly Version

Interactive Discussion 


\section{HESSD}

$7,1569-1587,2010$

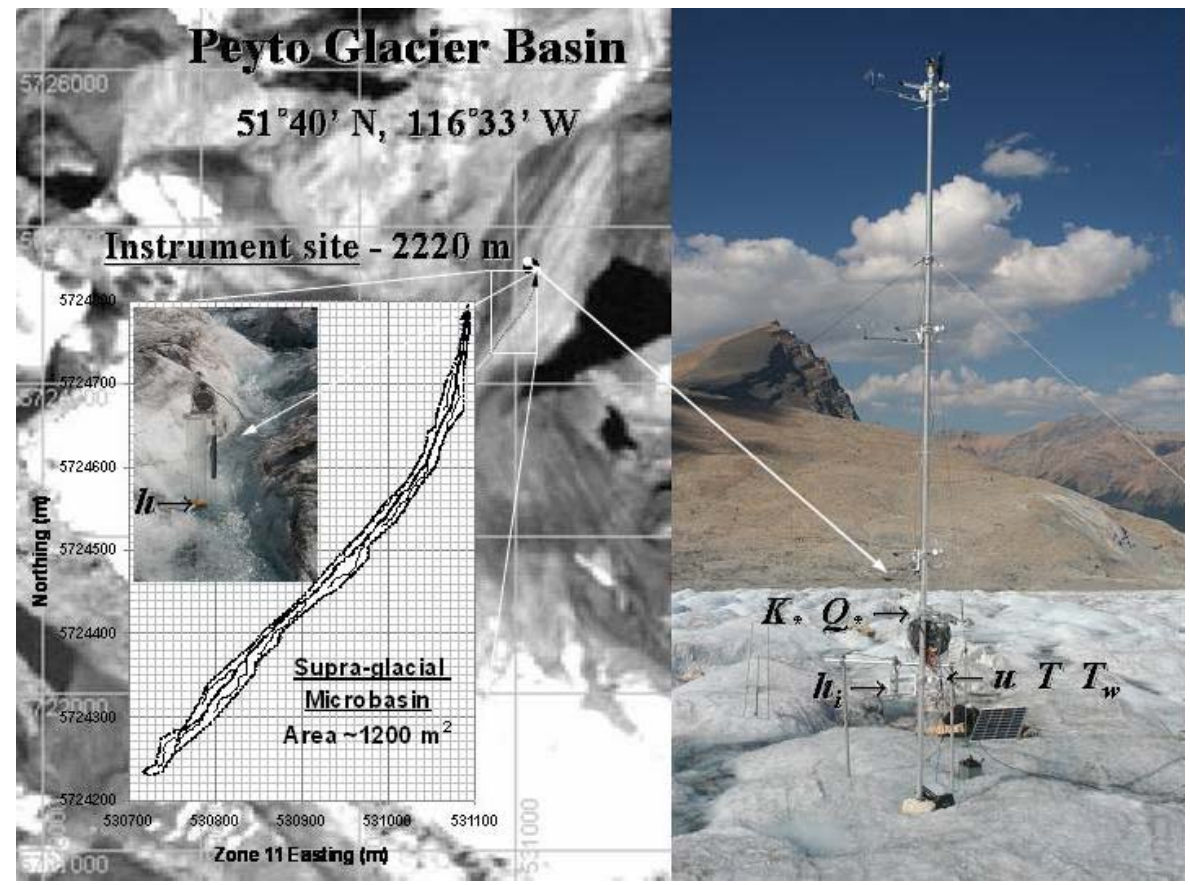

Fig. 1. Site and instrumentation for stage level, $h$, ice level, $h_{\mathrm{i}}$, net short-wave, $K_{*}$, and all-wave radiation, $Q_{*}$. Also, $1 \mathrm{~m}$ wind speed, $u$, dry-bulb, $T$, and wet-bulb temperature, $T_{\mathrm{w}}$, repeated at 2,4 and $6 \mathrm{~m}$ above the ice.

\section{Runoff response time of a loosely defined supraglacial microbasin \\ D. Scott Munro}

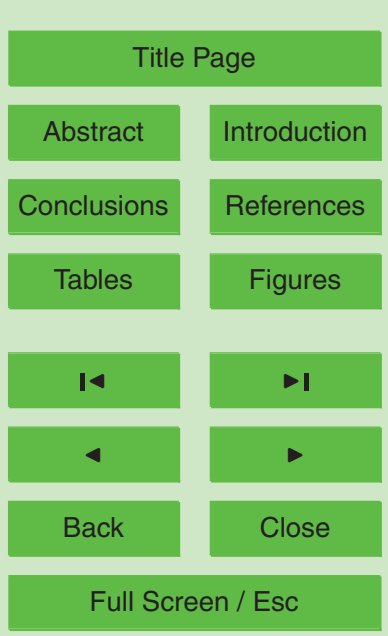

Printer-friendly Version

Interactive Discussion 


\section{HESSD}

$7,1569-1587,2010$

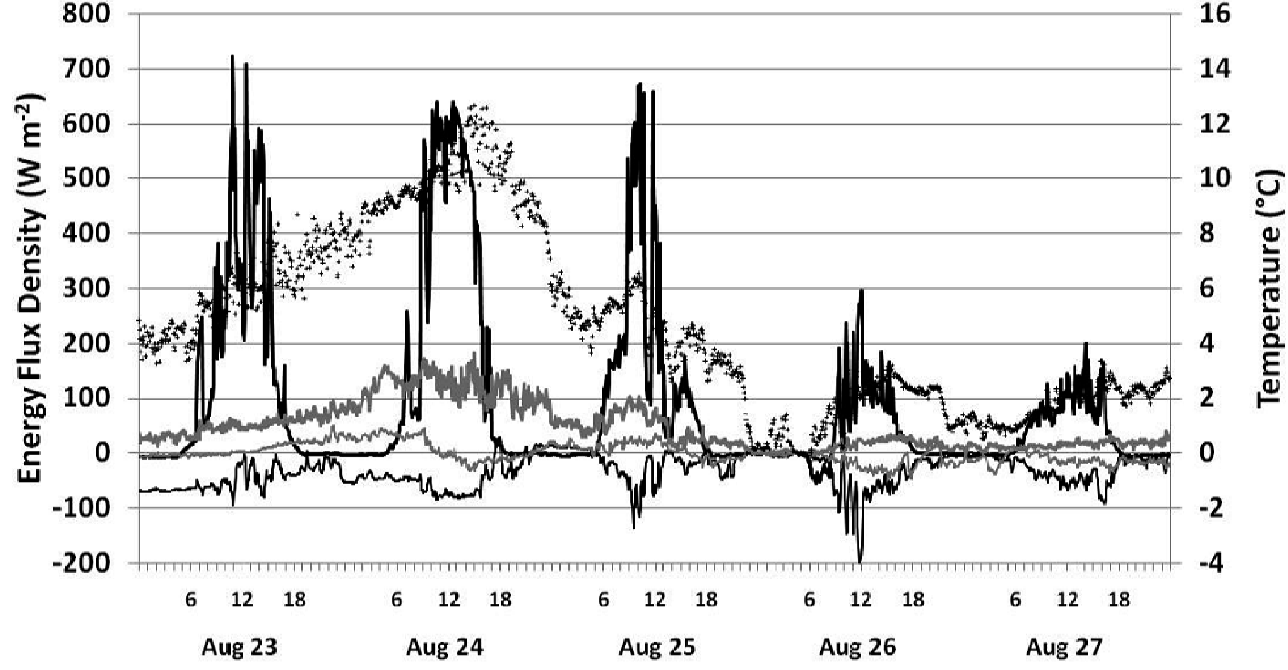

Fig. 2. Five-day energy series showing transition from three warm days of melt to two cold days of late summer snow cover. $K_{*}$ (thick black), $L_{*}$ (thin black), $Q_{\mathrm{H}}$ (thick grey) and $Q_{\mathrm{E}}$ (thin grey) decrease as air temperature $(+)$ changes from relatively warm $\left(>2^{\circ} \mathrm{C}\right)$ to relatively cold.
Runoff response time of a loosely defined supraglacial microbasin

D. Scott Munro

\section{Title Page}

\section{Abstract}

Conclusions

Tables

14

Back
Introduction

References

Figures

$\rightarrow$

Close

\section{Full Screen / Esc}

Printer-friendly Version

Interactive Discussion 


\section{HESSD}

$7,1569-1587,2010$

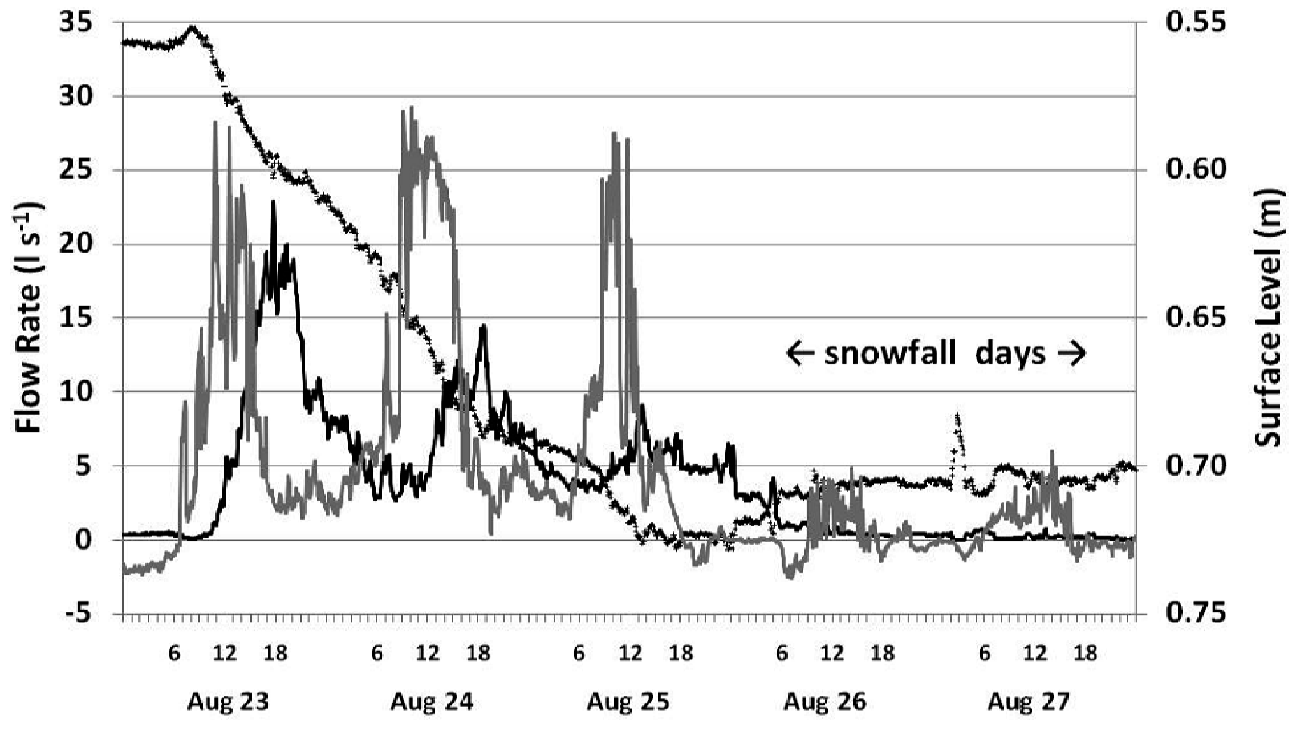

Fig. 3. Measured flow rates (black line) and flow rates estimated from the five-day energy series (grey line), compared with surface level (+).
Runoff response time of a loosely defined supraglacial microbasin

D. Scott Munro

Title Page
Abstract

Conclusions
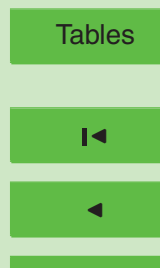

Back
Introduction

References

Figures

$\rightarrow$

$>$

\section{Full Screen / Esc}

Printer-friendly Version 


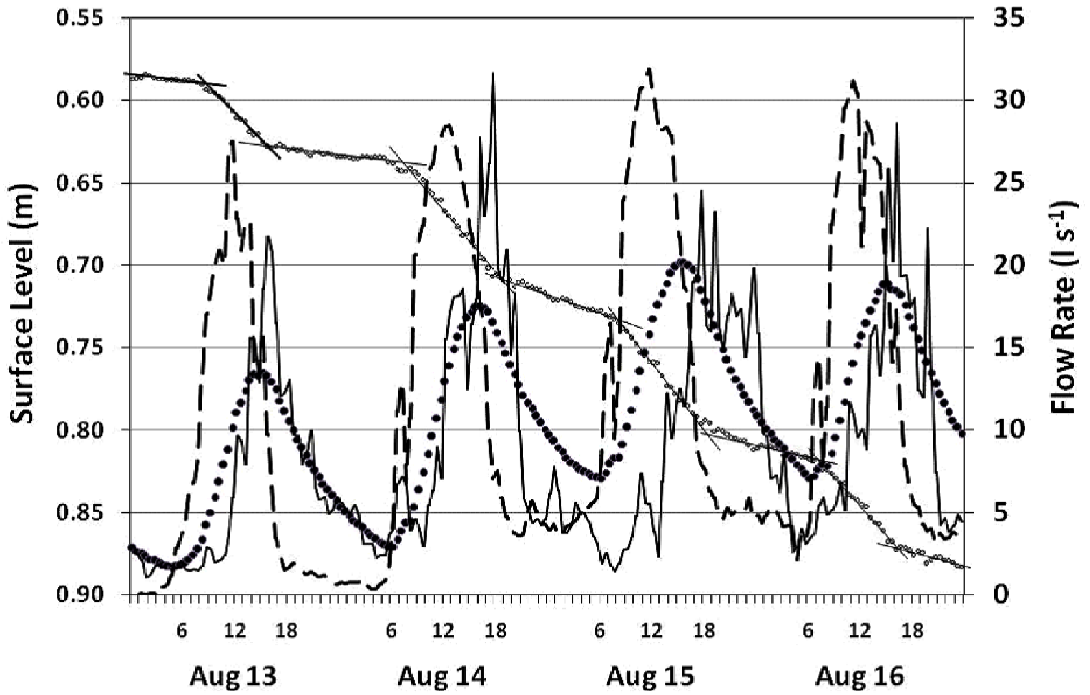

Fig. 4. Four-day melt series with half-hourly measured (solid line), estimated (broken line) and adjusted (dots) flow rates due to supraglacial runoff. Respective day and night segments of surface level change are the steep and shallow sloping straight line eye-fits to the ablation measurement points.
Runoff response time of a loosely defined supraglacial microbasin

D. Scott Munro

\section{Title Page}

\section{Abstract}

Conclusions

Tables

14

Back
Introduction

References

Figures

$\rightarrow$

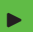

Close

\section{Full Screen / Esc}

Printer-friendly Version

Interactive Discussion 